\title{
PERTUMBUHAN BURUNG PUYUH (COTURNIX COTURNIX JAPONICA) UMUR 3 MINGGU DENGAN PERBEDAAN KEPADATAN DI DALAM KANDANG
}

\author{
Growth of Quail (Coturnix Coturnix Japonica) Age 3 weeks \\ with different quail density in cage \\ Syukri I. Gubali1 ${ }^{1)}$, Musrifah Nusi ${ }^{1)}$, Ellen J Saleh ${ }^{1}$ dan Jufri Pakaya ${ }^{2)}$ \\ 1) Animal Husbandry Departement, Faculty of Agriculture, Gorontalo State University \\ ${ }^{2}$ Alumni Animal Husbandry Departement, Faculty of Agriculture, Gorontalo State University \\ Corresponding Authors: Email: syukri.gubali65@gmail.com
}

\begin{abstract}
The purpose of this study was to determine the growth of quail aged 3 weeks, based on different cage densities. Completely randomized design was used during the study, with the density of quails in cages were $11(\mathrm{P} 1), 13$ (P2), 16 (P3), and 20 (P4). The results showed that differences in quail density in cages affected $(\mathrm{P}>0.05)$ body weight, consumption, and conversion of quail during rearing. the number of quail in the cage is 11 for a cage size of $35 \times 30 \times 40 \mathrm{~cm}$. Body weight, consumption, and conversion of feed produced at 3 weeks of age were: $95.52 \mathrm{gr}, 12.53 \mathrm{gr}, 0.13$
\end{abstract}

Keywords : Body Weight, Density Cage, Quail,

\begin{abstract}
ABSTRAK
Penelitian ini bertujuan untuk mengetahui pertumbuhan puyuh umur 3 minggu berdasarkan kepadatan kandang yang berbeda. Rancangan Acak Lengkap digunakan selama penelitian, dengan kepadatan puyuh di kandang adalah 11 (P1), 13 (P2), 16 (P3), dan 20 (P4). Hasil penelitian menunjukkan bahwa perbedaan kepadatan burung puyuh di kandang mempengaruhi $(\mathrm{P}>0,05)$ bobot badan, konsumsi, dan konversi pakan selama pemeliharaan. Jumlah puyuh dalam kandang adalah 11 ekor untuk ukuran kandang $35 \times 30 \times 40 \mathrm{~cm}$. Bobot badan, konsumsi, dan konversi pakan yang dihasilkan pada umur 3 minggu adalah: 95,52 gr, 12,53 gr, 0,13.
\end{abstract}

Kata Kunci : Burung puyuh, Bobot badan, Kepadatan Kandang, 


\section{PENDAHULUAN}

Peternakan unggas di Indonesia berkembang sangat pesat. Meskipun produksi ternak unggas masih didominasi oleh hasil produksi dari ayam, namun beternak burung puyuh juga mempunyai nilai ekonomis yang tinggi dan mulai berkembangdikalangan masyarakat. Burung puyuh mempunyai potensi yang cukup besar sebagai penghasil telur, beberapa diantaranya dapat bertelur lebih dari 300 butir dalam satu tahun produksi pertamanya.Kondisi tersebut terlihat dari kontribusi peternakan unggas dalam menyumbangkan protein hewani berupa daging dan telur terutama dalam pemenuhan kebutuhan makanan yang bernilai gizi tinggi.

Puyuh merupakan unggas daratan yang memiliki ukuran tubuh kecil, pemakan biji-bijian dan serangga kecil. Jenis puyuh yang sering dibudidayakan adalah puyuh Jepang (Coturnix coturnix japonica) puyuh ini mulai bertelur pada umur 42 hari dan beberapa keunggulan yang dimiliki oleh ternak puyuh diantaranya kemampuan produksi telurnya cepat dan tinggi (Listiyowati dan Roospitasari, 2009). (Ali et al., 2019)

Pertumbuhan puyuh mencakup pertambahan dalam bentuk dan berat jaringan-jaringan berupa protein seperti otot, tulang, jantung, otak dan jaringan tubuh lainnya. Bagian dari tubuh hewan tumbuh dengan cara yang teratur, meskipun tumbuh dengan teratur, tubuh tidak tumbuh sebagai suatu kesatuan, karena berbagai jaringan tumbuh dengan laju yang berbeda dari lahir sampai dewasa (Radhitya, 2015).

Bobot badan ternak senantiasa berbanding lurus dengan konsumsi ransum, makin tinggi bobot badannya, makin tinggi pula konsumsinya terhadap ransum. Konsumsi ransum dipengaruhi oleh tingkat energi ransum, imbangan zat nutrisi, suhu lingkungan, bentuk fisik ransum, bobot badan atau ukuran tubuh, kecepatan pertumbuhan, dan produksi. Asupan nutrisi yang dikonsumsi berkaitan dengan pertumbuhan. Pertumbuhan dapat terpenuhi karena adanya imbangan nutrisi yang dikonsumsi, tapi kurang memperhatikan kepadatan kandang karena mempengaruhi kenyamanan ternak. Kepadatan ternak dalam kandang merupakan faktor yang harus dipertimbangkan karena dalam tingkat kepadatan yang tinggi bisa menyebabkan kenaikan temperatur di dalam kandang, sedangkan pada tingkat kepadatan kandang yang rendah konsumsi pakan akan meningkat, produksi telur menurun, dan pertumbuhan ternak menurun karena terjadi pembuangan energi.Kandang dengan ukuran petak panjang $62 \mathrm{~cm}$, lebar 50 cmdan tinggi $26 \mathrm{~cm}$, idealnya diisi burung puyuh sebanyak 12 ekor. Menurut Sitorus, (2013), kepadatan kandang berpengaruhi pada konsumsi ransum, pertambahan bobot badan (Sitorus, (2013), produksi telur dan konversi ransum burung puyuh ((Ali et al., 2019). Populasi yang terlalu padat dapat mengakibatkan ternak bisa stres, sehingga menurunkan laju pertumbuhan dan produksi telur, sebaliknya populasi yang rendah dapat mengakibatkan efesiensi penggunaan kandang rendah.

Olehnya itudari uraian diatas maka telah dilakukan penelitian mengenai penampilanpertumbuhan burung puyuh umur 3 minggu dengan tingkat kepadatan kandang berbeda.

\section{METODE PENELITIAN}

Penelitian ini dilaksanakan selama tiga bulan dari bulan November 2020 sampai bulan Januari 2021, pada kandang percobaan di Kelurahan Leato Selatan Kecamatan Dumbo Raya Kota Gorontalo.

Adapun materi yang digunakan dalam penelitian ini adalah terdiri dari peralatatan berupa kandang batteray dengan ukuran $35 \times 30 \times 40 \mathrm{~cm}$ sebanyak 15 kotak yang diengkapi tempat makan dan tempat minum, timbangan analitik, alat tulis menulis, alat hitung, ember, gayung, sapu, alat dokumentasi dan lampu 
penerang. Sedangkan materi bahan yang digunakan pada penelitian ini adalah 180 ekor burung puyuh puyuh (unsex) umur 3 minggu, pakan butiran burung puyuh merek Comfeed sebanyak $60 \mathrm{~kg}$, air, vitamin dan obat-obatan.

Metode penelitian yang digunakan adalah Rancangan Acak Lengkap (RAL), sesuai yang disarankan. Penelitian ini menggunakan burung puyuh periode pertumbuhan (fase grower) berumur 3 minggu sebanyak 180 ekor (unsex) yang ditempatkan pada kepadatan kandang yang berbeda, yang terbagi dalam 4 perlakuan dengan 3 kali ulangan. Model matematika dari rancangan adalah :

\section{$Y i j=\mu+\beta i+\varepsilon i j$}

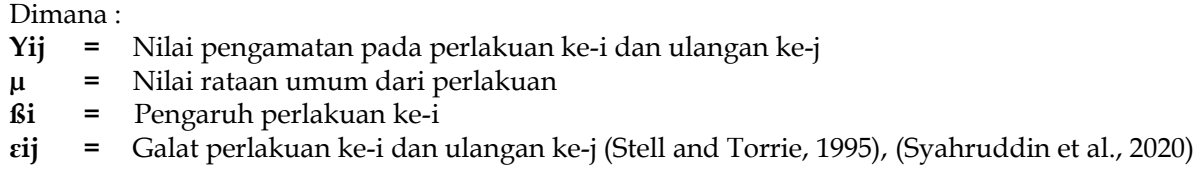

Adapun perlakuan dalam penelitian ini adalah :

$\mathrm{P}_{1}$ : Ukuran $35 \times 30 \times 40 \mathrm{~cm}$, kepadatan 11 ekor burung puyuh

$\mathrm{P}_{2}$ : Ukuran $35 \times 30 \times 40 \mathrm{~cm}$, kepadatan 13 ekor burung puyuh

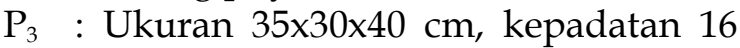
ekor burung puyuh

$\mathrm{P}_{4}$ : Ukuran $35 \times 30 \times 40 \mathrm{~cm}$, kepadatan 20 ekor burung puyuh

Parameter yang diamati pada penelitian ini adalah:

Bobot badan di peroleh dari hasil selisih penimbangan berat badan akhir dengan berat badan awal puyuh selama penelitian dilakukan setiap seminggu sekali (Rasyaf, 2011);Konsumsi pakan adalah jumlah pakan yang diberikan dikurangi sisa pakan yang tidak termakan (sisa) dibagi jumlah ternak (Anggorodi, 1995; Salau,
2015 ) ;Konversi pakan atau Feed Conversion Rate (FCR) merupakan perbandingan antara jumlah pakan yang dikonsumsi (gram) dengan bobot badan (gram) yang dihasilkan (Rokhana dan Waryani, 2016). Data hasil pegamatan dari peforma burung puyuh periode pertumbuhan umur 3 minggu yang meliputi bobot badan, konsumsi ransum, dan konversi ransum yang telah di peroleh dianalisis menggunakan analisis sidik ragam (ANOVA) dengan metode program SPSS. uji Duncan pada taraf kepercayaan $\alpha=0,05$ (Sastrosupadi, 2000).

\section{HASIL DAN PEMBAHASAN}

Berdasarkan hasil penelitian peforma pertumbuhan burung puyuh umur 3 minggu yang dipelihara pada tingkat kepadatan kandang yang berbeda tercantum pada Tabel 1.

Tabel 1. Rataan Variabel Penelitian dan Hasil Analisys Of Varian (ANOVA) Peforma Pertumbuhan Burung Puyuh Umur 3 Minggu yang Dipelihara pada Tingkat Kepadatan Kandang yang Berbeda.

\begin{tabular}{lccccccc}
\hline \multirow{2}{*}{ Variabel Peneletian } & \multicolumn{4}{c}{ Perlakuan } & \multicolumn{3}{c}{ Analisis Varian } \\
\cline { 2 - 5 } \cline { 6 - 8 } & P1 & P2 & P3 & P4 & F Hitung & 0.05 & F Tabel \\
\hline Konsumsi Ransum & 12,53 & 11,24 & 10,21 & 9,67 & $309.2^{\text {bn }}$ & & \\
Bobot Badan & 95,52 & 90,74 & 90,88 & 87,11 & $7.07^{\text {bn }}$ & 4.066 & 7.591 \\
Konversi Ransum & 0,13 & 0,13 & 0,11 & 0,11 & $29.06^{\text {bn }}$ & & \\
\hline
\end{tabular}

Keterangan: $\quad{ }^{\mathrm{tb}}=$ tidak berpengaruh

${ }^{\mathrm{bn}}=$ berpengaruh nyata

Angka yang diikuti huruf berbeda menunjukkan berbeda nyata pada taraf kepercayaan $5 \%$ dan $1 \%$ 


\section{Konsumsi Ransum}

Konsumsi Ransum adalah jumlah makanan yang di konsumsi oleh puyuh dalam jangka waktu tertentu. Kartasudjana dan Suprijatna (2006) yang menyatakan bahwa, konsumsi ransum dipengaruhi oleh temperatur lingkungan, bobot badan dan bentuk fisik ransum. Rata-rata konsumsi ransum burung puyuh pada tingkat kepadatan kandang yang berbeda dapat dilihat pada Gambar 1.

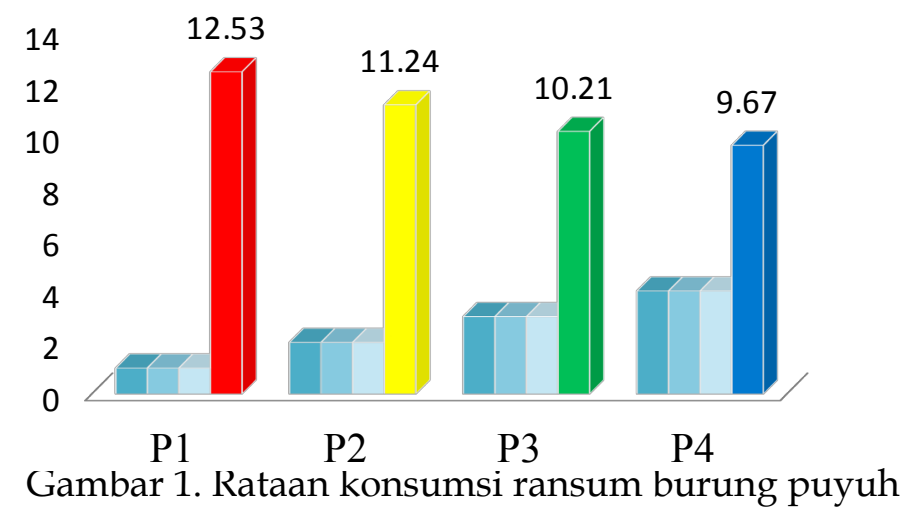

Rataan konsumsi ransum burung puyuh yang diperoleh pada setiap perlakuan memiliki perbedaan. Hasil penelitian menunjukkan bahwa, konsumsi ransum burung puyuh mengalami kenaikan. Rataan konsumsi ransum burung puyuh yang diperoleh yaitu 9,6712,53 gr/ekor. Hasil analisis statistik menunjukkan bahwa, peforma pertumbuhan burung puyuh umur 3 minggu yang dipelihara pada tingkat kepadatan kandang yang berbeda memberikan pengaruh nyata $(\mathrm{P}>0,05)$ terhadap konsumsi ransum burung puyuh. Hasil uji lanjut Duncan menunjukan bahwa, masing-masing perlakuan berbeda nyata.

Rataan konsumsi ransum pada penelitian ini lebih rendah jika dibandingkan dengan hasil penelitian yang dilakukan Florana dkk., (2017) yang menyatakan, rataan konsumsi ransum pada periode grower yaitu 18,33 gram/ekor/hari. Sedangkan Fransela et al. (2017) yang menyatakan, konsumsi ransum burung puyuh sebesar 23,32 gram/ekor/hari.

Hasil penelitian menunjukkan ratarata bahwa konsumsi ransum burung puyuh tertinggi yakni pada P1, sedangkan pada P2, P3, dan P4 mengalami penurunan. Konsumsi ransum tertinggi pada P1 disebabkan jumlah ransum yang diberikan sudah memenuhi kebutuhan puyuh, suhu lingkungan yang sudah sesuai, serta kualitas ransum. Pernyataan ini sejalan dengan pendapat Kartasudjana dan Suprijatna (2006) yang menyatakan bahwa, konsumsi ransum dipengaruhi oleh temperatur lingkungan, bobot badan dan bentuk fisik ransum. Suprijatna et al., (2005) juga menyatakan bahwa, faktorfaktor yang mempengaruhi konsumsi ransum yaitu kandungan nutrien ransum terutama energi dan protein. Protein memiliki fungsi untuk memenuhi kebutuhan pokok, pertumbuhan, dan produksi. Selain itu sebagai materi penyususn dasar semua jaringan tubuh yang dibentuk. jaringan tubuh tersebut berupa otot, sel darah, kuku, dan tulang.

Tingkat kepadatan kandang juga mempengaruhi jumlah konsumsi ransum burung puyuh dimana hal ini menyebabkan puyuh memiliki gerak luas di dalam kandang serta puyuh tidak mengalami stres. Tingkat kepadatan kandang burung puyuh yang semakin banyak menyebabkan konsumsi ransum mengalami penurunan pada P2, P3 dan P4 dibanding P1. Penurunan konsumsi ransum oleh burung puyuh disebabkan burung puyuh lebih banyak mengkonsumsi air minum dibandingkan 
ransum yang diberikan. Hal ini terjadi akibat tingginya suhu lingkungan di dalam kandang panas yaitu $34^{\circ} \mathrm{C}$ sehingga puyuh lebih banyak minum dibanding makan. Jumlah burung puyuh yang lebih sedikit maka jumlah konsumsi ransum semakin banyak. Artinya perbandingan jumlah burung puyuh di dalam kandang sudah sesuaidengan jumlah konsumsi ransum. Hal ini didukung pernyatan Kartasudjana dan Suprijatna (2006) yang menyatakan bahwa, konsumsi ransum dipengaruhi oleh temperatur lingkungan, bobot badan dan bentuk fisik ransum.

\section{Bobot Badan}

Bobot badan merupakan akumulasi hasil metabolisme. Hasil metabolisme didukung oleh banyaknya pakan yang dikonsumsi serta optimalisasi penggunaan pakan. Bobot badan di peroleh dari hasil selisih penimbangan berat badan akhir dengan berat badan awal puyuh selama penelitian dilakukan setiap seminggu sekali. Rata-rata bobot badan burung puyuh yang dipelihara pada tingkat kepadatan kandang yang berbeda dapat dilihat pada Gambar 2.

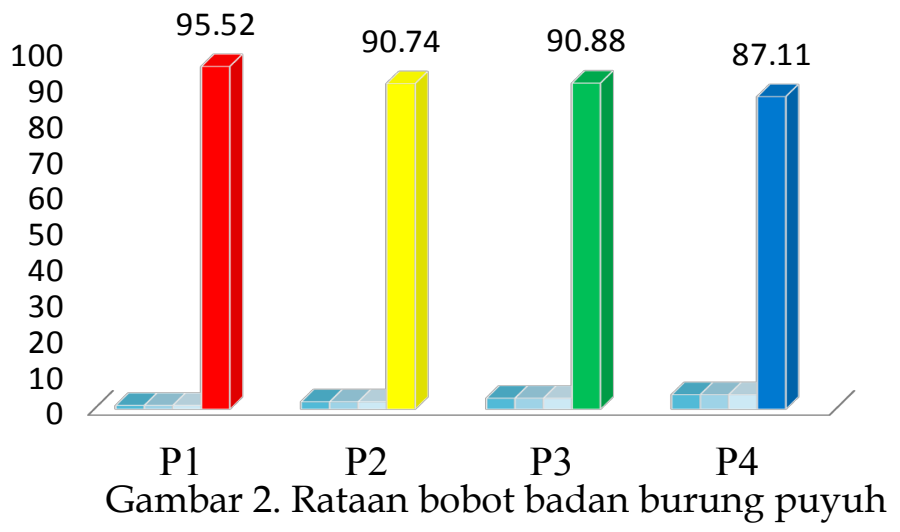

Rataan bobot badan burung puyuh yang diperoleh pada setiap perlakuan memiliki perbedaan. Hasil penelitian menunjukkan bahwa, bobot badan burung puyuh mengalami penurunan. Rata-rata bobot badan burung puyuh yang diperoleh pada penelitian ini antara 87,11 - 95,52 gr/ekor. Hasil analisis statistik menunjukkan, peforma pertumbuhan burung puyuh umur 3 minggu yang dipelihara pada tingkat kepadatan kandang yang berbeda memberikan pengaruh nyata $(\mathrm{P}>0,05)$ terhadap bobot badan burung puyuh. Hasil uji lanjut Duncan menunjukan bahwa, P2, P3, P4 berbeda nyata terhadap P1.

Raatan bobot badan burung puyuh pada penelitian ini lebih tinggi jika dibandingkan dengan hasil penelitian yang dilakukan oleh Irawan (2017) yang menyatakan bahwa, angka bobot badan burung puyuh fase grower sebesar 77,2 g/ekor. Tambunan dkk., (2013) menyatakan, raatan bobot badan burung puyuh pada fase grower sebesar 97-109,25 g/ekor. Hasil penelitian menunjukkan rata-rata bobot badan burung puyuh tertinggi yakni pada P1, sedangkan pada P2, P3, dan P4 mengalami penurunan. Bobot badan burung puyuh berbakaitan dengan jumlah konsumsi ransum, dimana tingkat kepadatan burung puyuh yang sedikit berpengaruh terhadap konsumsi ransum. Hal ini terbalik dengan tingkat kepadatan burung puyuh yang tinggi dimana terjadi penurunan jumlah konsumsi ransum yang mengakibatkan penurunan bobot badan seiring tingkat kepadatan berbeda pada P2, P3, dan P4.

Bobot badan burung puyuh pada P1 lebih tinggi karena burung puyuh memiliki gerak yang luas di dalam kandang sehingga tidak mudah mengalami stres yang dapat memberikan efek terhadap pola konsumsi ransum. Kondisi lingkungan yang panas turut memberikan pengaruh, hal ini menyebabkan burung puyuh lebih banyak 
mengkonsumsi air minum dibandingkan makan. Bobot badan burung puyuh mengalami kenaikan seiring pertambahan umurnya. Menurut Kurniansyah (2016) bahwa,bobot badan burung puyuh dengan umur 3-5 minggu dengan jenis kelamin betina yakni berkisar 64,66 - 101,94 gr, sedangkan burung puyuh dengan jenis kelamin jantan yakni berkisar 64,07 - 96,13 gr. Bobot badan burung puyuh yang didapat pada penelitian jauh lebih tinggi yakni berkisar antara 67,98 - 119,76 gr.

Konversi Ransum
Konversi pakan merupakan perbandingan antara jumlah pakan yang dikonsumsi (gram) dengan pertambahan berat badan setiap harinya (gram) yang dihasilkan pada waktu tertentu (Rasyaf, 2011). Amrulloh (2003) menyatahkan bahwa, faktor yang mempengaruhi tinggi rendahnya konversi ransum adalah kualitas ransum, teknik pemberian, bentuk dan konsumsi ransum. Rata-rata konversi ransum burung puyuh umur 3 minggu yang dipelihara pada tingkat kepadatan kandang yang berbeda dapat dilihat pada Gambar 3.

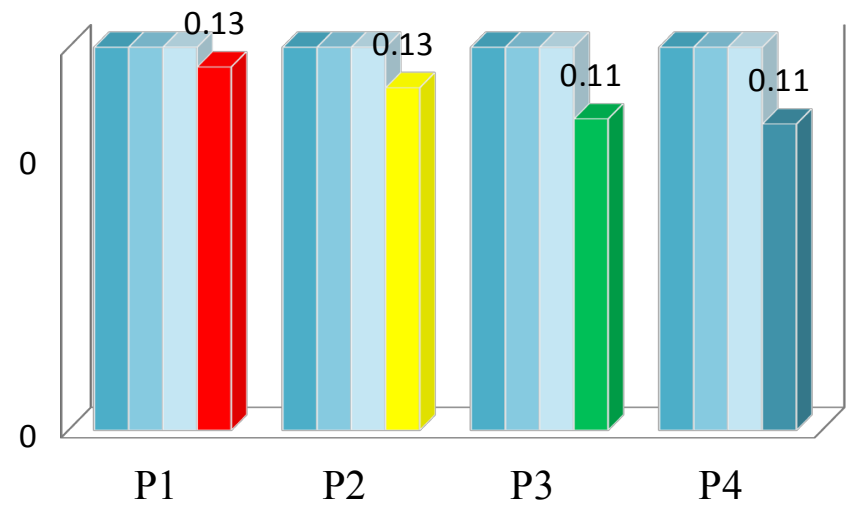

Gambar 3. Rataan konversi ransum burung puyuh

Rataan konversi ransum burung puyuh yang diperoleh pada setiap perlakuan memiliki perbedaan. Hasil penelitian menunjukkan bahwa, konversi ransum burung puyuh mengalami penurunan. Rataankonversi ransum burung puyuh yang diperoleh pada penelitian ini antara 0,11\%-0,13\%. Hasil analisis statistik menunjukkan bahwa, tingkat kepadatan kandang yang berbeda berpengaruh nyata $(P>0,05)$ terhadap konversi ransum burung puyuh. Hasil uji lanjut Duncan menunjukan bahwa, P1 dan P2 tidak berbeda nyata, begitu pula dengan P3 dan P4. Namun P1 dan P2 berbeda nyata terhadap P3 dan P4. Raatan konversi ransum pada penelitian ini jauh lebih rendah jika dibandingkan dengan hasil penelitian yang dilakukan oleh Widodo dkk. (2013) menyatakan, angka konversi ransum burung puyuh periode grower sebesar 3,67. Nilai konversi ransum pada puyuh petelur umumnya berkisar antara 2,68-3,40 (Mardiansyah, 2013).

Hasil penelitian menunjukkan ratarata konversi ransum burung puyuh tertinggi yakni pada P1, sedangkan rataan konversi ransum burung puyuh terendah yakni pada P4. Konversi ransum burung puyuh mengalami penurunan seiring pertambahan umur puyuh. Tingkat kepadatan kandang yang berbeda menyebabkan penurunan konversi ransum, ini berarti bahwa semakin padat kandang jumlah puyuh yang dipelihara dan adanya persaingandalam pengambilan pakan maka konversi ransum semakin rendah pula.

Konversi ransum yang rendah menggambarkan tingkat efisiensi penggunaan nutrisi pakan terhadap burung puyuh makin baik. Artinya tingkat 
efisiensi penggunaan pakan semakin tinggi. Pernyataan ini didukung oleh Subekti dan Hastuti (2013) yang menyatakan bahwa, konversi ransum merupakan ukuran efisiensi dalam penggunaan ransum. Semakin kecil nilai konversi ransum, maka semakin baik ternak dalam penyerapan ransum. Konversi ransum dapat digunakan sebagai gambaran untuk mengetahui tingkat efisiensi produksi. Angka konversi ransum yang rendah menandakan effisiensi ransum tinggi, sebaliknya angka konversi ransum yang tinggi menunjukkan nilai manfaat biologis yang rendah (Radhitya, 2015) dan kemampuan genetik ternak dalam memanfaatkan pakan (Masili, dkk 2019; Dako, 2019) Konversi pakan dipengaruhi oleh bangsa burung, manajemen, penyakit serta pakan yang digunakan (Ensminger, 1992).

\section{DAFTAR PUSTAKA}

Ali, L., Gubali, S. I., \& Saleh, E. J. (2019). PENAMPILAN PRODUKSI TELUR BURUNG PUYUH PADA TINGKAT KEPADATAN KANDANG YANG BERBEDA. Jambura Journal of Animal Science, 2(1). https:// doi.org/10.35900/jjas.v2i1.23 46

Amrulloh, I.K. 2003. Seri Beternak Mandiri: Nutrisi Ayam Broiler. Lembaga Satu Gunung Budi, Bogor.

Dako, S. (2019). Crossbreding Between Native Chiken And Leghorn Chiken Strain Isa Brown. Jurnal Peternakan, 16(1), 1-9.

Djulardi, A, H. Muis, Dan S. A. Latif. 2006. Nutrisi Aneka Ternak Dan Satwa Harapan. Fakultas Peternakan. Universitas Andalas, Padang.

Ensminger, M. A. 1992. Poultry science (Animal Agriculture Series). $3^{\text {rd }}$
Djulardi et al., (2006) menyatakan bahwa,imbangan nutrien seperti antara energi dan protein dapat mempengaruhi konversi ransum. Energi yang bersifat sebagai pembatas konsumsi ransum, maka apabila imbangan antar energi dengan protein yang terlalu luas seperti kandungan energi sangat tinggi, sedangakan protein sangat rendah akan menyebabkan berkurangnya konsumsi protein sehingga pertumbuhan mengalami hambatan.

\section{KESIMPULAN}

Kepadatan kandang ideal dan sangat baik untuk burung puyuh adalah 11 ekor untuk ukuran kandang $35 \times 30 \times 40 \mathrm{~cm}$. Peforma pertumbuhan burung puyuh umur 3 minggu yang dicapai pada bobot badan, Konsumsi pakan dan Konversi pakan adalah: 95,52 gr, 12,53 gr, 0,13 untuk nilai rataan per ekornya.

Edition. Interpublishers, Inc. Danville, Illinois

Florana, B., Dihansih, E., Handarini, R. 2017. Performa Puyuh Periode Starter-Grower Yang Diberi Ransum Imbuhan Mengandung Bawang Putih (Allium sativum) Dan Jintan (Cuminum cyminum). Jurnal Peternakan Nusantara ISSN 24422541. Vol. 3 (2).

Fransela Ch, Sarajar L.K, Montong M.E.R, Najoan M. 2017. Performans Burung Puyuh (Coturnix coturnix japonica) Yang Diberikan Tepung Keong Sawah (Pila ampullacea) Sebagai Pengganti Tepung Ikan Dalam Ransum. Jurnal Zootek Vol. 37 (1): 62 -69 .

Irawan, S. K. 2017. Pengaruh Pemberian Tomat Dalam Air Minum Terhadap Pertumbuhan Puyuh (Coturnixcoturnix Japonica) Di Daerah Tropis. Thesis. Universitas Jambi. 
Kartasudjana R, Suprijatna S. 2006. Manajemen Ternak Unggas. Penebar Swadaya. Jakarta.

Kurniansyah, G. 2016. Pengaruh Penggunaan Tepung Daun Kayambang (Salvinia molesta) Dalam Ransum Terhadap Pertumbuhan Fase Grower Puyuh Betina (Coturnix coturnix japonica). Skripsi. Fakultas Peternakan Dan Pertanian. Universitas Diponegoro.

Listiyowati, E. dan Roospitasari K. 2009. Beternak Puyuh Secara Komersial. Penebar Swadaya.

Masili, S., Dako, S., Ilham, F., \& Gubali, I. S. (2018). Heritabilitas Bobot Telur, Bobot Tetas Dan Bobot Badan Ayam Hasil Persilangan Umur 1 Minggu (DOC). Jambura Journal of Animal Science, 1(1), 1-5.

Mardiansyah, A. 2013. Performa Produksi Dan Organ Dalam Puyuh Diberi Pakan Mengandung Dedak Gandum Dan Tepung Daun Mengkudu. Skripsi Sarjana Peternakan. Institut Pertanian Bogor. Bogor.

Radhitya, A. 2015. Pengaruh Pemberian Tingkat Protein Ransum Pada Fase Grower Terhadap Pertumbuhan Puyuh (Cortunix cortunix japonica). Students Ejournal.4(2): 1-11.

Rasyaf M. 2011. Panduan Beternak Ayam Pedaging. Penebar Swadaya. Jakarta.

Rokhana, E., dan Waryani. 2016. Pengaruh Perbedaan Jenis Warna Cahaya lampu Dan Kepadatan Kandang Terhadap Performance Pada Pembesaran Burung Puyuh (Coturnix coturnix japonica) Jantan. Jurnal Fillia Cendekia, Vol. 1 (1).
SALAU, N. (2015). Pemberian Ekstrak Temulawak dalam air minum terhadap pertambahan bobot badan, konsumsi dan konversi pakan burung puyuh. Skripsi, 1(621410048).

Sastrosupadi, Adji. 2000. Rancangan Perobaan Praktis Bidang Pertanian. Kanisius, Yogyakarta.

Sitorus, T. F. 2013. Pengaruh Jenis Lantai dan Kepadatan Kandang Terhadap Performan Burung Puyuh Umur 3 Minggu Sampai 12 Minggu. Lembaga Penelitian, Universitas HKBP Nommensen, Medan

Syahruddin, S., Nahrowi, N., \& Yatno, Y. (2020). KEMAMPUAN POLISAKARIDA MANNAN SEBAGAI ORAL ADJUVAN VAKSIN AVIAN INFLUENZA PADA AYAM BROILER. Jambura Journal of Animal Science, 2(2), 90-101. https://doi.org/10.35900/jjas.v2i2.59 37

Steel R. G. D dan J. H Torrie. 1995. Prinsip dan Prosedur Statistika. Suatu Pendekatan Biometrik. (terjemahan) Edisi kedua. Gramedia Pustaka Utama. Jakarta.

Subekti. E, Dan Hastuti. D, 2013. Budidaya Puyuh Di Pekarangan Sebagai Sumber Protein Hewani Dan Penambah Income Keluarga. Jurnal Ilmu-Ilmu Pertanian. Mediagro. Vol 9. No 1. Hal 1-10.

Suprijatna. E, Almomarsono. U, Kartasudjana. R,. 2005. Ilmu Dasar Ternak Unggas. Cet 1. Penebar Swadaya. Jakarta.

Tambunan, G. M., Sarengat, W. dan Suprijatna, E. 2013. Pengaruh Penambahan Kotoran Walet Dalam Ransum Terhadap Performans Burung Puyuh Jantan Umur 0-5 
Minggu. Animal Agriculture Journal, Vol. 2. No. 1.

Wahju J. 1997.Ilmu Nutrisi Unggas. Gadjah Mada University Press. Yogyakarta.
Widodo A.R, Setiawan H, Sudiyono, Sudibyo, Indreswari R. 2013. Kecernaan Nutrien Dan Performan Puyuh (Coturnix coturnix japonica) Jantan Yang Diberi Ampas Tahu Fermentasi Dalam Ransum. Tropical Animal Husbandary Vol.2(1), 51-57 ISSN 2301-9921. 